\title{
REFLEKSI SISI NEGATIF BURUNG GAGAK DALAM PERIBAHASA MELAYU: ANALISIS SEMANTIK INKUISITIF
}

\author{
Muhammad Zaid DAUD*1 \\ Nurul Aida ABDULLAH ${ }^{2}$ \\ Mary Fatimah SUBET ${ }^{3}$ \\ ${ }^{1}$ Pusat Pembelajaran Bahasa, Universiti Teknikal Malaysia Melaka \\ ${ }^{2,3}$ Fakulti Bahasa dan Komunikasi, Universiti Malaysia Sarawak \\ 1 zaid.daud@utem.edu.my \\ 2nrlaida8915@gmail.com \\ ${ }^{3}$ sufatimah@unimas.my
}

\begin{abstract}
Manuscript received 20 November 2020
Manuscript accepted 17 November 2021

*Corresponding author

https://doi.org/10.33736/ils.2764.2021
\end{abstract}

\begin{abstract}
ABSTRAK
Pandangan masyarakat Melayu pada masa dahulu telah menginterpretasikan burung gagak sebagai rupa yang buruk, sesuatu yang lemah, impian yang tidak kesampaian dan sukar untuk berubah. Oleh itu, objektif khusus kajian ini adalah untuk meneroka sebab pemilihan imej perlambangan gagak dalam peribahasa Melayu menggunakan pendekatan Semantik Inkuisitif (Jalaluddin, 2014) serta dibantu dengan pendekatan Rangka Rujuk Silang (Kempson, 1986). Data peribahasa ini dikutip melalui pensampelan bertujuan dalam Kamus Peribahasa Melayu Edisi Kelima oleh Rahman (2017), Kamus Istimewa Peribahasa Melayu Edisi Kedua oleh Hussain (2016) serta Kamus Peribahasa Melayu oleh Said (2013). Keseluruhannya, terdapat sembilan data peribahasa Melayu yang bersumberkan burung gagak. Terdapat kajian terkini membuktikan burung gagak sebagai burung yang pintar, dapat menyelesaikan masalah dengan baik dan boleh mengekspresikan perasaan yang rumit. Tetapi, berdasarkan keintelektulan dan akal budi masyarakat Melayu, mereka masih merefleksikan burung gagak mempunyai sisi yang negatif. Contohnya, pengkhianatan, tikam belakang, ada kepentingan tersendiri dan menunggu masa untuk menjatuhkan seseorang. Rumusannya, penilaian orang Melayu pada zaman dahulu mengenai burung gagak telah diteliti dan dinilai secara kompleks.
\end{abstract}

Kata Kunci: Akal budi Melayu; gagak; peribahasa Melayu; semantik inkuisitif 


\title{
A Reflection on the Negative Side of Crows in Malay Proverbs: Inquisitive Semantics Analysis
}

\begin{abstract}
In the traditional Malay community, the crow is a symbol of ugliness, weakness, unfulfilled dreams, and difficult changes. This study explored the reasons for the symbolic use of crows in Malay proverbs using the Inquisitive Semantics Theory (Jalaluddin, 2014), as well as the Cross Reference Framework (Kempson, 1986). The proverbial data in this research was obtained by applying the purposive sampling method on three dictionaries: Kamus Peribahasa Melayu Edisi Kelima (Rahman, 2017), Kamus Istimewa Peribahasa Melayu Edisi Kedua (Hussain, 2016) and Kamus Peribahasa Melayu (Said, 2013). Nine Malay proverbs that mentioned "crows" were found. Despite recent studies proving that crows are intelligent birds; particularly in solving problems and expressing complex feelings, the Malay community's perception of the crow remains negative. In this regard, this study re-evaluated in depth the Malays' current and past views on crows.
\end{abstract}

Keywords: Malay intellect; crow; Malay proverbs; inquisitive semantics

\section{Pengenalan}

Elemen burung yang dijadikan imej perlambangan dalam peribahasa Melayu telah merepresentasikan sikap dan kelakuan manusia secara implisit, sama ada secara positif ataupun negatif (Daud, 2020). Menurut Wan Ismail (2016) antara imej perlambangan burung yang berasosiasi dengan nilai positif ialah belatuk (setia), berek-berek (muafakat), cenderawasih (kemewahan), denak (berani, kegagahan), tiung (kebaikan), garuda (kekuasaan) dan helang (ketangkasan, perkasa, pangkat dan kekayaan). Manakala, imej perlambangan burung yang berasosiasi dengan nilai negatif seperti cemperling (berlagak kaya), ciak (tipu daya), tempua (muslihat), kedidi (tidak tahu menjaga diri dan kejahatan), pungguk (perbuatan sia-sia) dan merak (sombong dan bangga diri).

Kajian ini bertujuan untuk mengkaji imej perlambangan gagak dalam peribahasa Melayu menggunakan pendekatan Semantik Inkuisitif (SI) oleh Jalaluddin (2014) serta dibantu pendekatan Rangka Rujuk Silang (RRS) oleh Kempson (1986) yang merupakan sebahagian daripada Teori Relevans (TR) oleh Sperber dan Wilson (1986). Berdasarkan makna harfiah yang dikemukakan oleh pengkaji yang lepas mengenai imej perlambangan gagak dalam peribahasa Melayu seperti Rahman (2017), Wan Ismail (2016), Hussain (2016) dan Said (2013) menunjukkan bahawa burung gagak ini membawa imej yang negatif. Contohnya, rupa yang buruk, lemah, impian yang tidak kesampaian dan sukar untuk berubah.

Berbeza pula dengan perspektif sains haiwan atau zoologi kerana burung gagak merupakan burung paling bijak dan cerdas di dunia, bahkan lebih bijak daripada burung 
kakak tua (Zulbadri et al., 2011). Gagak mempunyai otak yang besar dan berat jika hendak dibandingkan dengan saiz tubuh badannya yang kecil dan ringan. Werema (2015) pula telah menggelar burung gagak sebagai "flying monkey" atau "monyet yang boleh terbang" kerana tahap IQ burung ini yang lebih kurang sama dengan monyet. Tambah Werena (2015) kedua-dua haiwan (burung gagak dan monyet) ini mempunyai keupayaan seperti dapat menggunakan sesuatu alatan yang baik, boleh menyelesaikan masalah dan boleh mengekspresikan perasaan yang kompleks. Selain itu, burung gagak juga dapat memberi tindak balas jika berlakunya kematian burung gagak yang lain seperti berkicau dengan nada suram. Hal ini demikian kerana burung ini berupaya memahami "apa itu kematian". Dengan itu, burung ini akan mengelilingi bangkai burung gagak sebagai tanda hormat dan simpati atau dikenali sebagai "crow funeral" (Studios, 2020). Perkara ini telah menunjukkan bahawa burung gagak turut mempunyai nilai atau sisi yang positif dari sudut zoologi.

Oleh itu, timbulnya persoalan kenapakah dalam konteks masyarakat Melayu pada zaman dahulu hanya merujuk burung gagak ini kepada nilai atau sisi yang buruk sahaja? Di sinilah peranan SI yang digagaskan oleh Jalaluddin (2014) diaplikasikan. Dengan mempertalikan konsep "kenapa, kenapa dan kenapa" pengkaji dapat menemui sebab yang konkrit dalam pemilihan imej perlambangan yang digunakan dalam penciptaan sesebuah peribahasa. Kajian yang melibatkan pendekatan SI ini juga bersifat multidisiplin kerana bukan hanya pencungkilan makna bersifat harfiah dalam bidang bahasa dan linguistik diteliti, malahan, kajian sebegini telah berupaya menghubungjalinkan ke bidang ilmu yang lain seperti zoologi, kulinari, ekonomi, sains pertanian, dan politik.

\section{Sorotan Literatur}

Kajian mengenai burung gagak atau pengelasan saintifiknya daripada (1) alam: haiwan, (2) filum: Kardota, (3) kelas: Aves, (4) Oder: Passeriformes, (5) keluarga: Corvidae dan (6) Genus: Corvus (Linnaeus, 1758) telah banyak dijalankan oleh pengkaji yang lepas. Kajiankajian ini telah meliputi pelbagai perspektif ilmu seperti bidang zoologi, biologi, seni, sejarah, serta bidang bahasa dan linguistik.

Secara lahiriahnya, burung gagak diperlihatkan dalam bidang kajian zoologi yang merupakan subkajian biologi untuk mengkaji haiwan. Bagi kajian ini, pengkaji akan memfokuskan burung gagak sebagai data kajian. Terdapat juga subdisplin dalam bidang zoologi ini yang akan memfokuskan kajian mengenai burung sahaja. la dinamakan sebagai ornitologi. Antaranya pengkaji lepas yang menjalankan kajian dengan mengaitkan unsur gagak dalam bidang zoologi ialah Karar et al. (2016) dan Rahman et al. (2014). Karar et al. (2016) telah menjalankan kajian untuk mengetahui keanekaragaman, komposisi dan kemerataan jenis burung di hutan primer Suka Margasatwa Pulau Pasoso Kecamatan Balaesang Tanjung. Burung gagak mempunyai titik kehadiran yang dominan pada waktu pagi dan pada waktu petang dan mencatat jumlah nilai keanekaragaman $\left(H^{\prime}\right)$ sebanyak 0.1572 (lima ekor) (Karar et al., 2016). Ini 
jelas menunjukkan bahawa burung gagak wujud di kawasan hutan primer seperti kawasan kepulauan.

Rahman et al. (2014) pula telah menjalankan kajian untuk menguji kecekapan pengiraan dua spesies burung iaitu burung gagak dan burung tiong. Burung gagak lebih memilih tempat yang mempunyai cacing yang banyak pada frekuensi di atas peluang rawak (Rahman et al., 2014). Hal ini menunjukkan bahawa burung gagak berjaya dan bijak dalam mendiskriminasikan antara nombor makanan yang banyak dan nombor yang sedikit. Burung gagak merupakan haiwan jenis omnivorous, di mana burung ini turut makan serangga, buah-buahan dan bijirin. Walau bagaimanapun, burung gagak hanya memilih satu kombinasi makanan secara rawak yang sama dan memiliki kuantiti cacing yang banyak sahaja (Rahman et al., 2014). Menurut Rahman et al. (2014), burung gagak takut untuk mencuba sesuatu yang baru, tidak dapat memproses maklumat mengenai kuantiti dengan cara yang cekap dan hanya memilih makanan secara rawak. Burung gagak dapat menyesuaikan diri dengan mana-mana persekitarannya termasuk di kawasan yang pesat membangun seperti bandar raya (Rahman et al., 2014). Burung gagak ini dapat dijumpai di serata dunia kecuali di kawasan Antartika dan Selatan Amerika (Studios, 2020).

Di samping itu, akibat daripada perkembangan disiplin-disiplin ilmu yang lain, kajian mengenai burung gagak tidak terhad dalam pengkajian zoologi sahaja. Kajiankajian burung gagak telah menjangkau kepada bidang yang multidisplin, contohnya mampu menghubungjalinkan bidang zoologi dengan bidang agama. Kajian Zulbadri et al. (2011) mendapati bahawa perbandingan kelakuan burung dari sudut Islam dan neurosains terbahagi kepada enam kategori, iaitu (1) kelakuan terbang ke destinasi, keupayaan deria, (2) kelakuan penghasilan bunyi dan berlagu, (3) kelakuan keibubapaan, (4) kelakuan melakukan pergerakan khusus, dan (6) kelakuan-kelakuan lain. Kelakuan burung gagak dinyatakan dari sudut kelakuan penghasilan bunyi dan berlagu, kelakuan keibubapaan dan kelakuan melakukan pergerakan khusus. Bagi kelakuan penghasilan bunyi dan berlagu dari segi neurosains, burung gagak dinyatakan dapat menghasilkan bunyi suara dan penghasilan "lagu" seperti yang dapat dilakukan oleh burung dalam aturan Passeriformes. Burung gagak juga diklasifikasikan sebagai haiwan yang pintar, mempunyai daya pembelajaran yang baik sama seperti burung kakak tua.

Tambah Zulbadri et al. (2011), dari sudut Islam pula, keupayaan ini ada dinyatakan di dalam Al-Quran sebagai kelakuan bertasbih dan mentaati Allah. Kelakuan keibubapaan pula menyatakan bahawa burung gagak membuat seni bina sarang burung dengan menggunakan ranting dan wayar. Hal ini dikatakan demikian kerana Al-Quran telah menyatakan bahawa kelakuan penjagaan sebagai ibu bapa yang baik adalah melibatkan penyediaan rumah, habitat atau sarang sendiri. Dari perspektif neurosains pula, burung gagak mempunyai bahagian-bahagian otak hadapan, otak tengah dan otak belakang diperlukan oleh burung untuk membina sarang bersesuaian dengan lokasi dan keadaan persekitaran mereka. Akhir sekali dari sudut kelakuan melakukan pergerakan khusus, burung gagak ada disebut dalam Al-Quran seperti Surah Al-Ma'idah ayat 28 hingga 30. Kejadian ini menerangkan perkelakuan burung gagak yang mengorek tanah 
untuk mengebumikan bangkai burung gagak lain dan kemudian burung gagak ini menimbun kembali tanah tersebut. Dari perspektif neurosains, perbuatan burung menggali tanah untuk dan menimbuskannya kembali adalah berkait rapat dengan stuktur otaknya, di mana otak hadapan bertanggungjawab sebagai fungsi kognitif seperti mengenal pasti tempat yang hendak digali, otak tengah dikaitkan dengan penglihatan yang baik manakala otak belakang berperanan mengawal pergerakan terkawal dan halus. Pengkaji juga menyatakan bahawa burung gagak merupakan sejenis haiwan yang mempunyai kecerdikan dan kecekapan dalam mencari makanan seharian dan menangani masalah yang dilaluinya pada ketika itu.

Kajian Syauqi et al. (2018) pula bertujuan untuk memvisualisasikan dan mengungkapkan burung gagak sebagai idea dalam karya seni grafik. Berdasarkan kajian tersebut, burung gagak tidak semestinya membawa konsep "pesan kematian" seperti yang dianggap oleh masyarakat Indonesia; sebaliknya burung gagak juga boleh membawa kepada konsep yang positif seperti digambarkan oleh pengkaji dalam bentuk seni grafis. Antara konsep positif burung gagak yang divisualisasikan pengkaji melalui lukisan-lukisannya ialah konsep bertahan hidup, konsep komunitas, konsep intelegensi, konsep kesetiaan, konsep suka mandi, konsep eksekusi, konsep hukum, konsep kebiasaan, konsep tanggungjawab dan konsep mengintai.

Bagi fokus kajian ini, pengkaji akan menggunakan peribahasa Melayu berunsurkan gagak sebagai data kajian. Antara pengkaji lepas yang pernah menjalankan kajian mengenai peribahasa yang berkaitan dengan burung gagak seperti Widuri (2017), Hadi (2018), Wan Ismail (2016) dan Oemiati (2010). Widuri (2017) telah menganalisis makna Chengyu (peribahasa Mandarin) yang menggunakan unsur binatang berdasarkan konotasi dan fungsinya. Dalam kajian ini, penggunaan unsur burung gagak dalam chengyu didapati wujud dalam golongan chengyu yang mempunyai makna konotasi negatif dan makna konotasi neutral. Contoh chengyu unsur burung gagak bagi makna konotasi negatif ialah "wū hé zhī zhòng" (seperti sekumpulan gagak) yang bermaksud sekumpulan orang yang tidak disiplin dan liar, peribahasa ini digunakan untuk menggambarkan bandit (penyamun), pemberontak atau pasukan tentera yang tidak berguna. Manakala, peribahasa Mandarin lain yang menggunakan unsur gagak sebagai makna konotasi neutral ialah "yō què wú shēng" (tidak ada suara burung gagak mahupun burung gereja) yang bermaksud sunyi sepi ataupun senyap sekali. Dapatan kajian juga mendapati bahawa peribahasa Mandarin yang menggunakan unsur gagak mempunyai fungsi untuk memberi nasihat dan sindiran.

Hadi (2018) menjalankan kajian makna dan nilai budaya bagi peribahasa Jepun dan peribahasa Indonesia menggunakan kaedah Miles dan Huberman (1994). Pengkaji mendapati bahawa peribahasa Jepun menggunakan unsur burung gagak sebagai makna tentang meniru orang lain, manakala peribahasa Indonesia pula menggunakan ikan sebagai lambang yang mempunyai makna yang sama. Dapatan kajian Hadi (2018) mendapati bahawa, perbandingan nilai budaya peribahasa Jepun dan Indonesia yang menggunakan unsur burung gagak hanya wujud dalam nilai budaya realiti dalam hidup iaitu sikap menerima kenyataan dalam diri. 
Oemiati (2010) pula mendapati bahawa perumpamaan bahasa kiasan dalam bahasa Jepun yang menggunakan imej perlambangan burung gagak turut dikesan dalam novel Yukiguni. Bahasa kiasan mengenai burung gagak ini memberi makna yang negatif. Imej perlambangan burung gagak (karasu), dalam novel digunakan untuk menggambarkan aktiviti para biksuni yang naik dan turun untuk meminta sedekah kepada masyarakat untuk membeli keperluan makan. Burung gagak dijadikan lambang kepada keadaan para biksuni yang berpenampilan bersahaja seperti memakai sandal jerami dan tudung cetok.

Sebelum ini, telah terdapat kajian mengenai unggas yang menggunakan pendekatan SI. Antara imej perlambangan unggas yang dikaji ialah ayam, burung, itik dan angsa (Daud, 2018a, 2020), ayam dan musang (Daud, 2018b), ayam sahaja (Daud \& Subet, 2019a, 2019b, 2021) serta angsa dan itik (Daud \& Subet, 2019c). Sebagai kelompangan kajian lepas ini, pengkaji berpendapat perlunya pengkajian mengenai SI dalam menganalisis peribahasa Melayu yang memfokuskan data unggas secara khusus. Contohnya, burung gagak. Walaupun, kajian mengenai burung gagak telah dijalankan dalam pelbagai perspektif ilmu, namun kajian-kajian tersebut tidak berupaya meneroka imej perlambangan burung gagak dengan mengaitkan akal budi sesebuah masyarakat seperti kajian ini dilaksanakan.

\section{Metodologi Kajian}

Kajian ini adalah berbentuk kualitatif. Pengkaji mengaplikasikan analisis dokumen bagi mendapatkan data peribahasa bersumberkan burung gagak secara pensampelan bertujuan. Bagi menganalisis data peribahasa ini pengkaji telah mengaplikasikan pendekatan SI oleh Jalaluddin (2014). Rajah 1 merupakan ringkasan bagi kerangka SI pada tahap pertama yang dinamakan sebagai semantik skrip. Pada peringkat ini pengkaji menyaring data peribahasa berunsurkan gagak yang terdapat dalam Kamus Peribahasa Melayu Edisi Kelima oleh Rahman (2017), Kamus Istimewa Peribahasa Melayu Edisi Kedua oleh Hussain (2016) serta Kamus Peribahasa Melayu oleh Said (2013). Melalui data peribahasa yang terdapat dalam kamus ini, pengkaji telah memperoleh sebanyak sembilan data peribahasa Melayu yang mempunyai imej perlambangan gagak berdasarkan pensampelan bertujuan. Jadual 1 menunjukkan contoh peribahasa Melayu yang mempunyai imej burung gagak. Namun begitu, data peribahasa ini hanya diberikan makna harfiah tanpa melibatkan kognitif, teori mahupun akal budi Melayu itu sendiri.

Oleh sebab pemberian makna peribahasa pada Tahap 1 tidak memadai untuk mendalami peribahasa ini, analisis diteruskan pada tahap kedua, iaitu semantik resonans. Pada peringkat ini, makna peribahasa tidak dilihat melalui makna dasarnya sahaja, namun makna peribahasa ini telah berupaya mengaitkan data, kognitif dan teori dalam menginterpretasikan makna peribahasa tersebut secara lebih berpada. Dalam konteks kognitif peribahasa berunsurkan gagak ini dapat dikelaskan kepada nilai-nilai yang khusus. Contohnya, kejahatan, tuah, kemiskinan, perkahwinan atau kekeluargaan, harapan serta rupa paras seseorang (Malaycivilization.com). Pada tahap kedua ini, perlunya sokongan teori yang berwibawa dalam menginterpretasikan makna peribahasa 
ini secara kognitifnya. Oleh itu, pada tahap ini pengkaji akan menggunakan pendekatan RRS oleh Kempson (1986) yang merupakan sebahagian daripada TR oleh Sperber dan Wilson (1986). Menurut Ritos dan Daud (2020), penerapan teori yang mampan seperti TR dan RRS diperlukan supaya huraian data disokong dan mampu membentuk aturan konsepsi dan membekalkan kemudahan bagi menjelaskan fenomena yang kompleks dalam berbahasa. Dengan adanya konteks, kesan kognitif yang tinggi terhadap penggunaan peribahasa Melayu berunsurkan burung gagak ini akan menyebabkan usaha memproses yang rendah. Pada tahap ketiga, SI dapat mencungkil makna tersirat secara lebih mendalam serta tidak terhenti di peringkat kognitif dan skrip sahaja. Oleh itu, penerokaan makna lebih berwibawa dapat dilakukan sehingga mendapat satu jawapan mengapa imej gagak digunakan dalam penciptaan peribahasa tersebut.

\section{Rajah 1}

Kerangka Semantik Inkuisitif oleh Jalaluddin (2014)

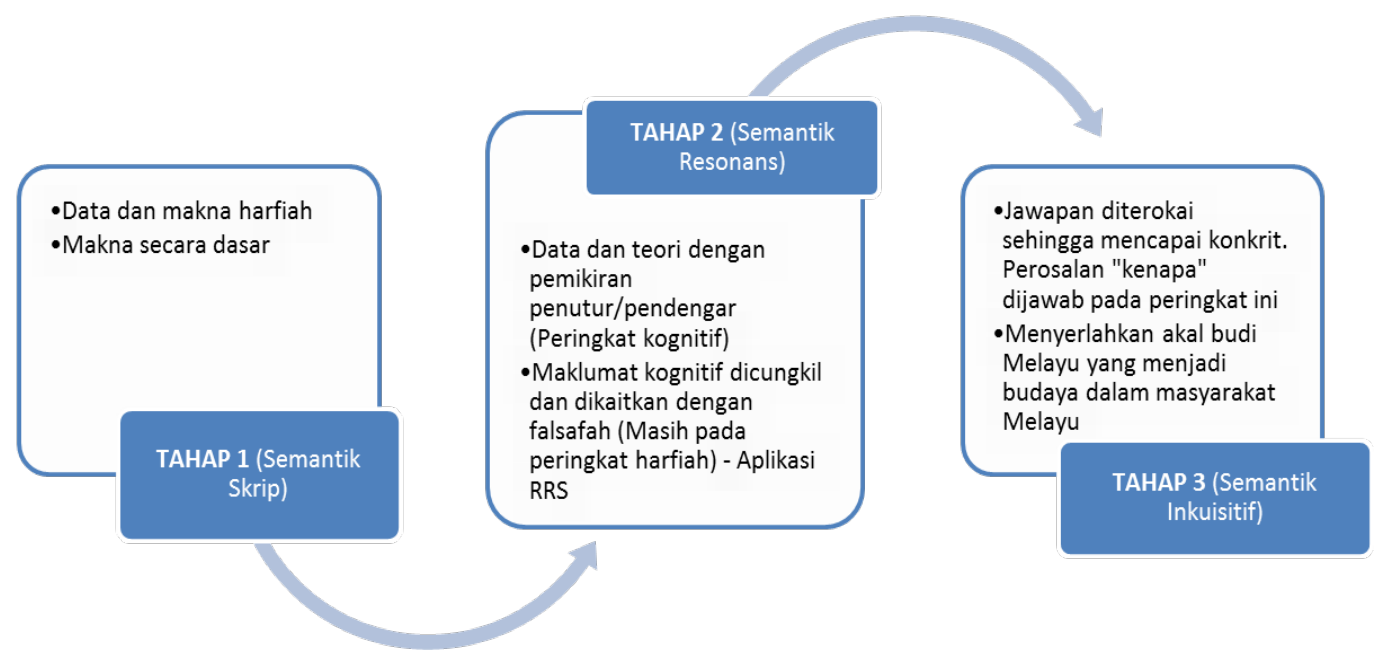

\section{Analisis dan Perbincangan}

Pembentukan peribahasa Melayu berunsurkan gagak dapat dirujuk melalui contoh peribahasa dalam Jadual 1.

\section{Jadual 1}

Contoh Peribahasa Melayu yang Mempunyai Imej Perlambangan Gagak

\begin{tabular}{ccc}
\hline Peribahasa Melayu & Maksud & Nilai \\
\hline Bagai gagak & Perempuan hodoh & Orang; kahwin; \\
menggonggong telur & berpakaian bagus & kekeluargaan \\
Burung gagak itu jika & Orang biasa jahat itu biar & Jahat \\
dimandikan dengan air & bagaimanapun &
\end{tabular}




\begin{tabular}{|c|c|c|}
\hline $\begin{array}{l}\text { mawar sekalipun, } \\
\text { tidak akan menjadi } \\
\text { putih bulunya }\end{array}$ & $\begin{array}{c}\text { dinasihatkan namun } \\
\text { tabiatnya tidak dapat } \\
\text { diubah }\end{array}$ & \\
\hline $\begin{array}{l}\text { Seperti mendapat } \\
\text { gagak putih }\end{array}$ & Peroleh yang bertuah & Tuah \\
\hline $\begin{array}{c}\text { Gagak pulang ke } \\
\text { benua }\end{array}$ & $\begin{array}{l}\text { Pulang daripada merantau } \\
\text { tetapi tidak tetap berubah }\end{array}$ & Miskin \\
\hline $\begin{array}{l}\text { Hitam gagak tiada } \\
\text { siapa yang } \\
\text { mencelupnya }\end{array}$ & $\begin{array}{l}\text { Menjadi jahat atas pilihan } \\
\text { sendiri }\end{array}$ & Jahat \\
\hline Gagak bersuara murai & $\begin{array}{c}\text { Rupanya hodoh tetapi } \\
\text { suaranya merdu dan baik } \\
\text { budi bahasanya }\end{array}$ & Hodoh; berbudi-bahasa \\
\hline $\begin{array}{c}\text { Gagak putih, bangau } \\
\text { hitam }\end{array}$ & $\begin{array}{c}\text { Mengharapkan yang } \\
\text { mustahil }\end{array}$ & Harapan \\
\hline
\end{tabular}

Jadual 1 menunjukkan peribahasa Melayu yang menggunakan imej perlambangan burung gagak secara semantik skrip. Seterusnya, pengkaji akan mengaplikasikan RRS dengan TR untuk dikaitkan dengan teori dan konteks. Peringkat ini dinamakan sebagai semantik resonans, dan merupakan penambahbaikkan pemberian makna peribahasa di peringkat semantik skrip.

\section{Refleksi Gagak Berkonsepkan “Rupa yang Buruk”}

Konsep "rupa yang buruk" dapat dilihat melalui peribahasa Melayu "bagai gagak menggonggong telur" yang bermaksud perempuan hodoh yang berpakaian bagus (Said, 2013). Para pendengar ataupun pembaca perlu mempunyai rujukan yang berasal daripada pengalaman ataupun pengetahuan sedia ada untuk mendapatkan perkaitan yang optimum. Jadi, RRS dibentuk oleh pendengar melalui contoh ayat ini:

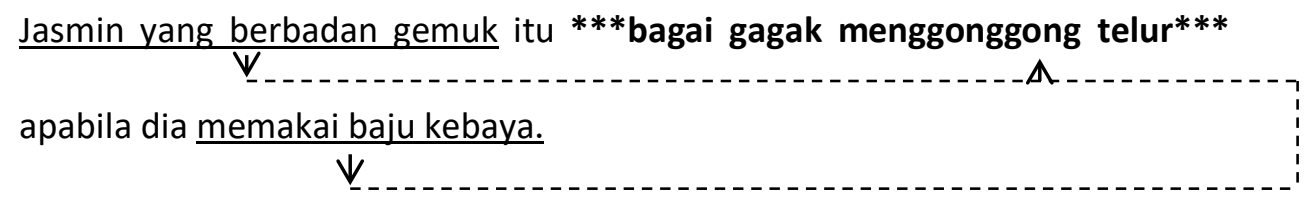

(Sumber: Said, 2013)

Berdasarkan contoh ayat tersebut, frasa yang bergaris dapat dijadikan sebagai maklumat tambahan kepada pembaca ataupun pendengar bagi menginterpretasikan makna peribahasa "bagai gagak menggonggong telur". Peribahasa ini biasanya digunakan oleh masyarakat Melayu ketika melihat seseorang perempuan yang mempunyai penampilan yang hodoh ataupun rupa yang buruk, tetapi berpakaian cantik. 


\section{Analisis Rangka Rujuk Silang}

Bagi memahami makna sebenar peribahasa tersebut, pendengar perlu mempunyai rujukan yang berasal daripada pengalaman atau pengetahuan sedia ada untuk mendapatkan relevan yang maksimum (Abdullah \& Daud, 2020). Pembaca secara tidak langsung akan memahami peribahasa dengan bantuan maklumat tambahan yang diberikan dalam sesuatu ujaran. RRS yang dibentuk oleh pendengar melalui maklumat tambahan itu ialah:

1. Seorang perempuan hodoh berpakaian cantik.

Andaian ini dihasilkan berdasarkan dua klausa dalam contoh ayat iaitu "Jasmin yang berbadan gemuk" dan "memakai baju kebaya". Adjektif "gemuk" secara tidak langsung menyebabkan pendengar membayangkan unsur-unsur yang negatif dan rupa serta penampilan seorang perempuan yang bernama Jasmin dalam konteks ayat tersebut. Merujuk kepada peribahasa itu sendiri, seekor gagak yang dapat diandai oleh pembaca sebagai seekor burung berwarna hitam dan sedang menggonggong telur yang dapat digambarkan mempunyai sifat permukaan kulit yang licin dan berwarna putih. Keduadua objek ini telah menunjukkan perbezaan yang sangat ketara antara seekor gagak dan telur.

\section{Analisis Teori Relevans}

Pendengar boleh mentafsir makna ujaran bagi peribahasa bagai "gagak menggonggong telur" dengan mudah kerana adanya maklumat tambahan yang diberikan melalui RRS. Penggunaan anteseden "berbadan gemuk" dan "memakai baju kebaya" membolehkan pendengar mendapatkan kesan kognitif yang tinggi. Anteseden tersebut telah memberi gambaran yang jelas kepada pendengar iaitu seorang wanita yang berbadan gempal sedang menggayakan dirinya dengan berbaju kebaya. Berdasarkan pengamatan pendengar kebiasaannya wanita yang memiliki badan yang langsing, tubuh badan dan rupa yang cantik sahaja memakai baju kebaya. Dengan adanya kesan kognitif yang tinggi, pendengar sudah boleh mentafsir makna sebenar peribahasa tersebut dengan lebih mudah lagi. Jadi secara tidak langsung, RRS tersebut membantu memberi kesan kognitif yang tinggi kepada pendengar untuk memahami peribahasa ini. Berdasarkan TR, jika kesan kognitif itu tinggi, maka usaha memproses makna tersebut secara tidak langsung menjadi rendah (Samaon \& Subet, 2020a, 2020b). Dengan pengetahuan yang sedia ada yang dibekalkan melalui konteks tadi, pembaca dapat memikirkan dan mengaitkan imej gagak yang berwarna hitam diabstrakasikan sebagai seorang perempuan yang hodoh iaitu "rupa yang buruk", manakala telur yang mempunyai permukaan kulit yang licin dan mengandungi protein yang tinggi dan sumber vitamin serta mineral pula diabstrakasikan sebagai berpakaian cantik (berkebaya) seperti contoh ayat tersebut.

Seterusnya, peribahasa "gagak bersuara murai" yang bermaksud rupanya hodoh, tetapi suaranya merdu dan baik budi bahasanya (Hussain, 2016). Makna harfiah bagi peribahasa tersebut boleh difahami oleh pembaca ataupun pendengar dengan merujuk 
maknanya di kamus ataupun melalui pengetahuan pendengar yang sedia ada. Jadi, bagi mendapatkan perkaitan yang lebih optimum, para pendengar perlu mempunyai rujukan, pengalaman dan pengetahuan yang lebih mendalam bagi menginterpretasikan makna peribahasa tersebut. Dengan adanya RRS ataupun konteks andaian, pendengar boleh membentuk satu andaian iaitu:

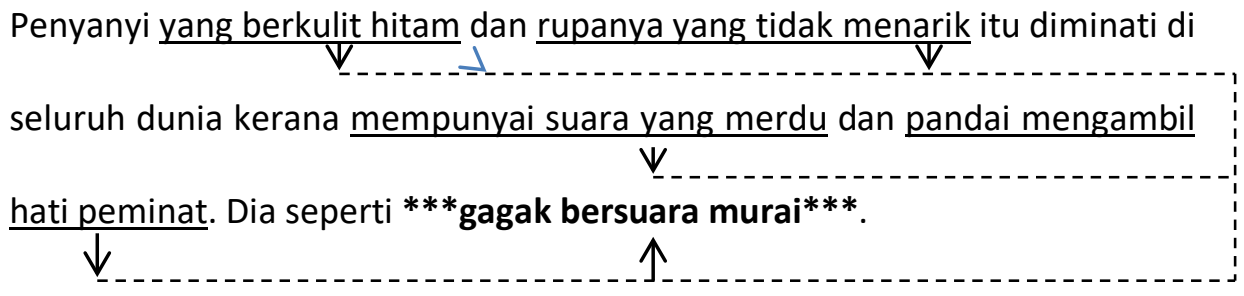

(Sumber: Said, 2013)

Contoh ayat tersebut mengandungi empat maklumat tambahan bagi memudahkan pendengar menginterpretasikan makna sebenar yang dihajati. Peribahasa ini kebiasaannya digunakan oleh masyarakat untuk menggambarkan seseorang yang mempunyai suara yang lunak dan merdu serta mempunyai budi pekerti yang tinggi akan tetapi rupa parasnya tidak cantik ataupun hodoh. Dengan adanya andaian melalui RRS, pendengar akan dapat memahami perkaitan dalam peribahasa ini dengan lebih mendalam lagi.

\section{Analisis Rangka Rujuk Silang}

Bagi memahami makna peribahasa tersebut, pendengar perlu mempunyai rujukan yang berasal daripada pengalaman atau pengetahuan sedia ada untuk mendapatkan relevan yang maksimum. Pembaca secara tidak langsung akan memahami peribahasa ini walaupun tidak mengetahui makna di sebalik peribahasa tersebut dengan adanya maklumat tambahan yang diberikan. Berdasarkan anteseden "berkulit hitam", "rupanya yang tidak menarik", "mempunyai suara yang merdu" dan "pandai mengambil hati peminat", pendengar mampu memahami ujaran terebut dan selanjutnya dapat mengaitkannya dengan peribahasa "gagak bersuara murai". RRS yang dibentuk oleh pendengar melalui maklumat tambahan itu ialah:

1. Seseorang yang mempunyai rupa yang tidak menarik akan tetapi memiliki suara yang merdu.

\section{Analisis Teori Relevans}

Melalui RRS yang dikemukakan, peribahasa tersebut telah memberikan kesan kognitif yang tinggi. Anteseden seperti "berkulit hitam", "rupanya yang tidak menarik", "mempunyai suara yang merdu" dan "pandai mengambil hati peminat" yang diberikan di dalam RRS membolehkan pendengar untuk memproses makna tersirat peribahasa 
tersebut dengan lebih mudah lagi. Anteseden "berkulit hitam" dan rupanya yang tidak menarik secara tidak langsung dapat dikaitkan dengan gambaran "gagak" bagi peribahasa ini. Seiring dengan keadaan fizikal seekor burung gagak yang berwarna hitam. Manakala anteseden mempunyai suara merdu dan pandai mengambil hati peminat pula dapat dikaitkan dengan frasa "bersuara murai"

Hal ini demikian kerana, burung murai dikenali sebagai seekor jenis burung yang mempunyai kicauan yang merdu bahkan burung murai juga sangat terkenal dalam kalangan penggemar burung kerana burung ini mudah dijinakkan dan patuh pada tuannya. Jadi, peribahasa gagak bersuara murai menggunakan imej gagak yang memiliki bulu yang hitam sebagai gambaran kepada seseorang yang rupanya hodoh akan tetapi memiliki suara yang merdu seperti kicauan burung murai. Dengan adanya maklumat rujukan melalui RRS, kesan kognitif pendengar terhadap makna peribahasa tersebut juga meningkat lalu merendahkan usaha memproses pendengar dalam menginterpretasikan makna peribahasa ini.

\section{Refleksi Gagak Berkonsepkan "Sesuatu yang Lemah"}

Peribahasa yang mempunyai imej perlambangan gagak berkonsepkan "sesuatu yang lemah" ialah gagak pulang ke benua. Peribahasa tersebut bermaksud pulang daripada merantau tetapi tidak tetap berubah dan terletak di bawah nilai miskin. Bagi mendapatkan perkaitan yang lebih relevan, pendengar mahupun pembaca memerlukan pengetahuan yang sedia ada, pengalaman dan maklumat rujukan bagi memudahkan interpretasi makna yang sebenar. Oleh itu, RRS yang dibentuk oleh pendengar ialah:

Encik Ahmad yang baru sahaja pulang ke kampungnya masih kekal miskin

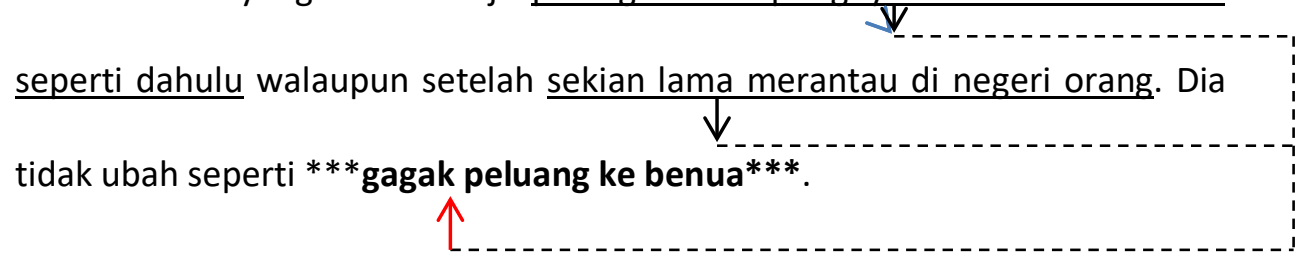

(Sumber: Said, 2013)

Berdasarkan contoh ayat di atas, terdapat maklumat rujukan yang boleh membantu pendengar mendapatkan perkaitan makna sebenar pada tahap yang unggul. Peribahasa ini kebiasaannya digunakan oleh masyarakat untuk merujuk kepada seseorang yang sudah lama merantau di tempat orang tetapi nasibnya masih kekal sama setelah balik ke kampung halaman.

\section{Analisis Rangka Rujuk Silang}

Bagi memahami makna peribahasa tersebut, pendengar perlu mempunyai rujukan yang berasal daripada pengalaman atau pengetahuan sedia ada untuk 
mendapatkan relevan yang maksimum. Pembaca secara tidak langsung akan memahami peribahasa ini walaupun tidak mengetahui makna di sebalik peribahasa tersebut dengan adanya maklumat tambahan yang diberikan. Jadi, andaian yang mungkin dapat dibentuk oleh pendengar berdasarkan maklumat tambahan tersebut ialah:

1.Pulang dari merantau, tetapi tidak tetap berubah.

Andaian ini dibentuk berdasarkan anteseden "pulang", "kekal miskin" dan "setelah lama merantau di negeri orang". Leksikal "pulang" secara langsung mempunyai persamaan penggunaannya dalam peribahasa gagak "pulang” ke benua.

\section{Analisis Teori Relevans}

Dengan RRS yang dibina oleh pendengar mahupun pembaca berdasarkan pengetahuan ataupun pengalaman yang sedia ada, pendengar boleh mentafsir makna peribahasa gagak pulang ke benua dengan lebih mudah. Hal ini selanjutnya akan memberi kesan kognitif yang tinggi dan merendahkan usaha memproses pendengar kerana mempunyai maklumat rujukan yang cukup untuk memahami makna peribahasa tersebut. Berdasarkan contoh ayat yang diberikan, pendengar boleh membuat andaian seekor gagak yang berbulu hitam akan tetap kekal rupanya apabila ia pulang ke benua walaupun burung gagak tersebut telah terbang beribu kilometer jauh sekalipun. Melalui RRS, imej perlambangan burung gagak dikaitkan dengan seorang individu yang pergi merantau untuk mengubah corak kehidupannya, tetapi tetap balik dengan nasib yang sama dan tidak berubah. Hal ini tidak ubah seperti burung gagak yang kekal berbulu hitam setelah balik ke benua.

\section{Refleksi Gagak Berkonsepkan “Impian yang Tidak Kesampaian”}

Konsep "impian yang tidak kesampaian" dapat dilihat melalui peribahasa "gagak putih, bangau hitam". Makna peribahasa "gagak putih, bangau hitam" ialah mengharapkan sesuatu yang mustahil (Said, 2013). Peribahasa ini jelas menujukkan bahawa seseorang itu menantikan sesuatu yang mustahil akan berlaku seperti bulu seekor gagak yang berwarna hitam akan menjadi putih dan sebaliknya bagi seekor bangau. Jadi, pendengar harus mempunyai rujukan daripada pengalaman ataupun pengetahuan yang sedia ada bagi memperoleh perkaitan yang lebih unggul berkenaan dengan peribahasa tersebut. Maka, konteks andaian yang mungkin dibentuk oleh pendengar berdasarkan peribahasa tersebut ialah:

Sikap Faizul yang hanya duduk di rumah dan mengharapkan seseorang datang

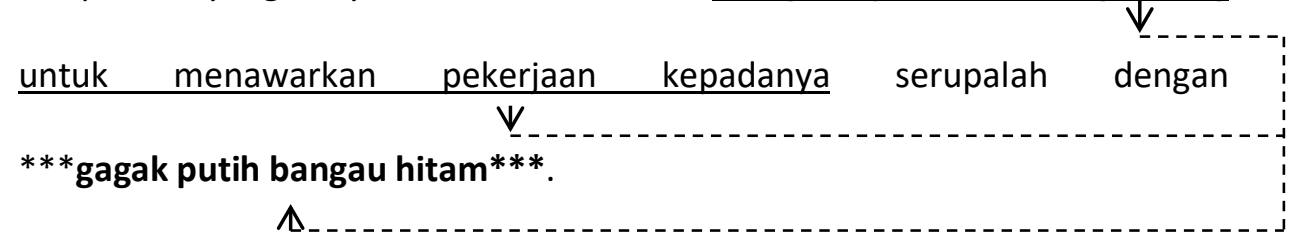


(Sumber: Said, 2013)

Contoh ayat ini dapat membantu pendengar memahami maksud peribahasa tersebut, walaupun tidak mengetahui makna peribahasa sebelum ini. Rujukan maklumat tambahan "mengharapkan seseorang datang untuk menawarkan pekerjaan kepadanya" sedikit sebanyak membantu pembaca untuk menginterpretasikan makna tersirat peribahasa "gagak putih bangau hitam" dengan lebih baik.

\section{Analisis Rangka Rujuk Silang}

Bagi menginterpretasikan peribahasa ini, pendengar perlu mempunyai rujukan melalui pengetahuan sedia ada pendengar itu sendiri untuk mendapatkan relevan yang maksimum. RRS yang dibentuk oleh pendengar adalah:

\section{Mengharapkan sesuatu yang mustahil.}

Andaian tersebut dibentuk berdasarkan anteseden mengharapkan seseorang datang untuk menawarkan pekerjaan kepadanya. Perkataan "mengharapkan" memainkan peranan yang penting dalam contoh ayat tersebut bagi menginterpretasikan makna peribahasa "gagak putih, bangau hitam". Maklumat rujukan yang diberikan dalam contoh ayat tersebut secara tidak langsung membantu pendengar untuk memahami peribahasa tersebut dengan lebih baik.

\section{Analisis Teori Relevans}

Maklumat rujukan "mengharapkan seseorang datang untuk menawarkan pekerjaan kepadanya" sememangnya memberi kesan kognitif yang tinggi kepada pendengar untuk memahami makna tersirat peribahasa tersebut. Pendengar mampu memahami peribahasa ini dan seterusnya mengetahui secara tersurat burung gagak sememangnya berbulu berwarna hitam dan burung bangau pula berwarna putih di seluruh tubuhnya. Perkara ini telah membantu pendengar memperoleh kesan kognitif tinggi dan memudahkan usaha memproses pendengar untuk memahami makna tersirat peribahasa tersebut. Pendengar juga dapat mengaitkan dengan pengalaman hidup mereka sendiri mengenai sifat semula jadi kedua-dua jenis burung kerana seekor gagak yang berwarna putih ataupun bangau yang berwarna hitam adalah sangat mustahil. Andaian yang wujud ini boleh berdiri kukuh kerana TR membenarkan kita untuk memikirkan andaian-andaian yang akan membantu dalam menginterpretasikan makna yang sebenarnya.

\section{Refleksi Gagak Berkonsepkan "Kesukaran untuk Berubah"}

Peribahasa "burung gagak itu jika dimandikan dengan air mawar sekalipun, tidak akan menjadi putih bulunya" bermaksud orang biasa jahat itu biar bagaimanapun 
dinasihatkan, namun tabiatnya tidak dapat diubah (Said, 2013). Peribahasa ini dapat diklasifikasikan dalam nilai kejahatan. Andaian yang dapat difikirkan oleh pendengar melalui RRS ialah:

Adapun dari hal Tuan Raffles itu sebab kurang siasatnya akan mengerjakan pekerjaan yang besar itu menjadi sesallah ia pada kemudiaannya tiada berguna. Karena telah diketahuinya tabiat manusia yang jahat itu sangatlah susahnya hendak membaiki akan dia melainkan ia mendapat petunjuk daripada Allah. Seperti kata arif burung ${ }^{* * *}$ gagak itu jikalau dimandikan dengan air mawar sekalipun, tiada akan menjadi putih bulunya***, yang hitam itu adanya.

(Sumber: Said, 2013)

Terdapat dua maklumat rujukan dalam ayat ini yang boleh membantu pendengar menginterpretasikan makna yang diingini. Anteseden "tabiat manusia yang jahat" dan "sangatlah susahnya hendak membaiki akan dia melainkan ia mendapat petunjuk daripada Allah" boleh dijadikan rujukan oleh pendengar untuk memahami makna peribahasa ini.

\section{Analisis Rangka Rujuk Silang}

Berdasarkan maklumat tambahan yang diberikan, pendengar mampu memahami peribahasa tersebut seterusnya mengetahui bahawa burung gagak yang berbulu hitam legam di seluruh tubuhnya tidak akan bertukar menjadi putih walau disiram dengan menggunakan air mawar. Jadi, konteks andaian yang dibentuk oleh pendengar ialah:

1. Orang biasa jahat itu biar bagaimanapun dinasihatkan, namun tabiatnya tidak dapat diubah.

\section{Analisis Teori Relevans}

Berdasarkan andaian yang dibuat berdasarkan konteks, peribahasa ini sebenarnya mempunyai kesan kognitif yang sangat tinggi. Melalui anteseden "tabiat manusia yang jahat dan sangatlah susahnya hendak membaiki akan dia melainkan ia mendapat petunjuk daripada Allah", pendengar boleh memahami makna peribahasa yang diberikan pada ayat ketiga. Maklumat tambahan yang diberikan dalam contoh ayat 
tersebut menerangkan bahawa seseorang yang jahat itu sangat susah untuk kita nasihatkannya untuk berubah kerana sudah terbiasa berbuat jahat melainkan individu tersebut mendapat hidayah daripada Allah. Apabila kesan kognitif tinggi, maka usaha memproses pendengar secara tidak langsung menjadi rendah. Bertitik tolak daripada konteks tersebut, pendengar secara tidak langsung juga dapat mengaitkan sikap seseorang yang berbuat jahat dengan gagak yang mempunyai tubuh badan yang hitam. Anteseden "jahat" dan "hitam" kedua-duanya mempunyai aura yang negatif, maka bagi peribahasa tersebut burung gagak dijadikan sebagai gambaran seseorang yang mempunyai perwatakan yang jahat. Air mawar pula sangat terkenal dalam dunia kecantikan kerana air mawar boleh mencerahkan kulit wajah (Seli, 2018). Peribahasa ini menyatakan bahawa burung gagak itu jika dimandikan dengan air mawar sekalipun, tiada akan putih bulunya. Hal ini menjelaskan bahawa warna burung gagak yang hitam tidak akan berubah dan akan tetap kekal hitam waima dimandikan dengan air mawar sekalipun. Berkesinambungan dengan sikap seseorang yang sudah biasa berbuat jahat, walaupun seseorang menasihatinya untuk berubah, dia tetap tidak akan berubah. Hal ini seterusnya secara tidak langsung memberikan kesan kognitif yang tinggi kepada pendengar ditambahkan lagi dengan adanya maklumat tambahan melalui RRS.

\section{Pengaplikasian Semantik Inkuisitif dalam Peribahasa Melayu Berunsurkan Gagak}

Pada bahagian ini, pengkaji akan mempersoalkan pemilihan leksikal yang terdapat dalam peribahasa berunsurkan gagak ini. Oleh itu, berikut merupakan leksikal/frasa tambahan yang berkolokasi dengan peribahasa berunsurkan gagak ini.

\section{Rajah 2}

Leksikal/Frasa Tambahan dalam Pembentukan Peribahasa Berunsurkan Gagak

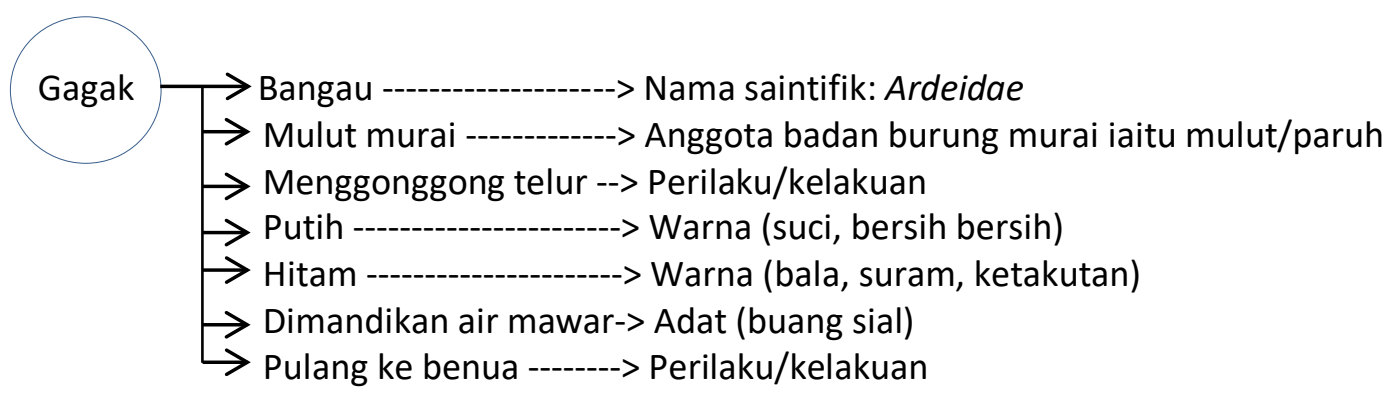

Dalam peribahasa Melayu berunsurkan gagak, burung ini turut digandingkan dengan imej perlambangan burung yang lain contohnya, burung murai dan bangau. Menurut Nopiah et al. (2017) dalam kajian peribahasa Melayu konsep dikenali sebagai "dualisme". Konsep ini dibentuk berdasarkan penilaian orang Melayu pada masa lalu terhadap sifat dan tingkah laku orang di sekelilingnya, objek dan imej yang mereka lihat, rasa dan dengar lazimnya bersumberkan alam. 


\section{Jadual 2}

Imej Perlambangan Burung Gagak Berasosiasi dengan Burung Murai dan Bangau dalam Peribahasa Melayu

\begin{tabular}{|c|c|c|}
\hline Imej burung & Nilai positif & Nilai negatif \\
\hline Gagak & $\mathrm{x}$ & $\begin{array}{l}\text { Rupa yang buruk, kelemahan, impian } \\
\text { yang tak kesampaian, sukar untuk } \\
\text { berubah }\end{array}$ \\
\hline Murai & $\begin{array}{l}\text { Ahli dalam bidangnya, } \\
\text { waktu (masa) }\end{array}$ & Bercakap banyak dan kecoh \\
\hline Bangau & Jati diri & $\begin{array}{l}\text { Berkepentingan diri, tidak tetap } \\
\text { pendirian, iri hati }\end{array}$ \\
\hline
\end{tabular}

(Sumber: Wan Ismail, 2016)

Kenapa masyarakat Melayu pada zaman dahulu melambangkan jenis burung ini, malahan menggantikan sifat zoologi burung tersebut antara satu sama lain? Contohnya, peribahasa "gagak putih, bangau hitam". Melalui sudut SI, peribahasa "gagak putih bangau hitam" menimbulkan banyak persoalan kepada pendengar. Mengapa masyarakat Melayu menggunakan kata adjektif "hitam" dan "putih" dalam peribahasa tersebut dan kenapa imej perlambangan yang digunakan ialah burung gagak dan burung bangau? Kata adjektif "putih" dapat diertikan sebagai warna yang paling cerah seperti warna kapas dan berlawanan dengan warna hitam. Warna putih juga dikonsepsikan sebagai warna yang bersih, suci dan murni (Kamus Dewan Edisi Keempat, 2016).

Dari sudut pandangan psikologi, warna putih dikaitkan dengan unsur-unsur yang positif seperti unsur kemurnian, kesucian, keselamatan, kecemerlangan, syurga, kebersihan, keimanan, kesempurnaan dan sebagainya (Kusrianto, 2009). Warna putih juga mampu untuk mengurangi rasa takut dan gusar kerana warna ini memberi kesan kebebasan dan keterbukaan. Warna putih dianggap sebagai satu warna yang murni, suci dan bersih kerana warna putih tidak memerlukan apa-apa campuran (Abdullah, 2018).

Sebaliknya warna hitam menggambarkan makna yang bertentangan dengan sifat warna putih. Warna hitam didefinisikan sebagai warna seperti arang, lawan putih, dianggap tidak selamat. Menurut Abdullah (2018), kebanyakan orang akan takut dengan warna hitam kerana ramai yang percaya bahawa warna hitam mengundang bala, suram dan ketakutan. Walau bagaimanapun, warna hitam juga ditakrifkan sebagai warna yang misteri, kebebasan, dramatis dan kesunyian. Dalam dunia fesyen, warna hitam digolongkan sebagai warna yang solid, tegas, kuat dan bila dikombinasikan, warna hitam akan menyerlahkan hasil yang lebih menarik (Ibrahim \& Halid, 2020). Jadi, berbalik kepada peribahasa Melayu iaitu "gagak putih, bangau hitam", peribahasa ini jelas menunjukkan sifat fizikal yang bertentangan mengenai kedua-dua jenis burung tersebut.

Dari segi pengetahuan masyarakat Melayu yang sedia ada, mereka sedia maklum bahawa burung gagak ataupun nama saintifiknya Corvus memiliki tubuh atau bulu badan, paruh dan kaki yang berwarna hitam, manakala telur burung gagak pula berwarna biru berbintik hitam. Hal ini dapat membuktikan bahawa warna hitam dan 
burung gagak berpisah tiada kerana burung gagak sememangnya sangat signifikan dikaitkan dengan warna hitam. Manakala, burung bangau pula ataupun nama saintifiknya bulbucus merupakan sejenis burung bangau yang terdapat di Malaysia yang berasal daripada keluarga Ardeidae. Kebiasaannya burung bangau mempunyai tubuh badan ataupun bulu yang berwarna putih dan kakinya berwarna kehitam-hitaman (Anim, 2018).

Akan tetapi peribahasa Melayu tersebut meletakkan ciri-ciri yang bertentangan di mana gagak dikatakan berwarna putih, manakala bangau dikatakan berwarna hitam. Secara fitrahnya, bagi menemukan seekor gagak yang berwarna putih dan bangau yang berwarna hitam sememangnya satu perkara yang mustahil untuk berlaku. Oleh itu, peribahasa ini dapat dikaitkan secara langsung dengan situasi mengharapkan sesuatu yang mustahil (Said, 2013).

Selain itu, peribahasa berunsurkan burung gagak turut diasosiasikan dengan mandi bunga mawar. Melalui perspektif SI, peribahasa Melayu ini menggunakan perlambangan "air mawar" bagi memutihkan bulu burung gagak. Menurut Kamus Dewan Edisi Keempat (2016), air mawar merupakan air yang harum baunya iaitu air yang disuling daripada bunga mawar. Mandi pula ialah satu perbuatan mencuci ataupun membasuh tubuh dengan air. Jadi, mandi air mawar dapat diklasifikasikan sebagai membersihkan tubuh dengan menggunakan air yang telah disulingkan daripada bunga mawar.

Dalam masyarakat Melayu, mandi air mawar merupakan salah satu adat istiadat yang diamalkan oleh masyarakat tersebut dengan alasan untuk "membuang sial", membuang nasib malang atau nasib kurang baik dalam tubuh seseorang (Seli, 2018). Adat ini pula sebenarnya berasal daripada adat kaum Jawa dan mandi air mawar dalam masyarakat Jawa juga bertujuan untuk membuang sial ataupun mengelak daripada berlaku sebarang malapetaka yang boleh menjejaskan kehidupan mereka suatu hari kelak (Erwany, 2016). Adat mandi air mawar ini menggunakan pelbagai jenis bungabungaan dalam angka ganjil iaitu sama ada tujuh, sembilan ataupun 11 jenis bunga bersama dengan limau purut (Abdullah et al., 2019).

Mokhtar et al. (2018) ada menyenaraikan beberapa jenis bunga yang digunakan dalam adat mandi air mawar berserta dengan fungsinya. Antara jenis bunga-bunga yang digunakan di dalam adat mandi air mawar dalam masyarakat Melayu ialah bunga mawar merah untuk tujuan berani, bertenaga dan berkeyakinan tinggi, bunga mawar putih untuk rasa segar, nyaman dan suci, bunga cempaka putih dan kuning untuk tujuan melembutkan kulit dan aroma yang harum, melur kuning untuk menyucikan dalaman, melur putih pula untuk merapatkan bahagian intim. Manakala, bunga kenanga berfungsi untuk menaikkan seri. Masyarakat Melayu percaya bahawa penggunaan bunga-bunga tersebut dalam adat mandi air mawar boleh memberikan aura yang positif kepada gadis yang mencari jodoh ataupun untuk menaikkan seri pengantin sebelum bergelar raja sehari (Paul et al., 2019).

Berdasarkan pemilihan jenis bunga yang dinyatakan, hal ini jelas menunjukkan bahawa masyarakat Melayu bijak memilih jenis-jenis bunga kerana fungsi-fungsi bunga tersebut bukannya sekadar kepercayaan karut semata-mata. Jadi, apakah perkaitan 
mandi air mawar dalam adat istiadat masyarakat Melayu dengan peribahasa ini? Berdasarkan pengetahuan yang sedia ada mengenai mandi air mawar dalam kalangan masyarakat Melayu bertujuan untuk membuang nasib malang, menjauhkan diri seseorang daripada ditimpa malapetaka, menaikkan seri wajah seseorang dan untuk memberikan aura positif kepada seseorang itu.

Apakah falsafah masyarakat Melayu pada zaman dahulu mengaitkan mandi air mawar dengan intuisiti burung gagak? Hal ini secara tidak langsung dapat dikaitkan dengan keadaan fizikal burung gagak yang berwarna hitam tubuhnya dan mempunyai aura yang negatif misalnya burung gagak merupakan lambang pembawa sial, tanda penyihir jahat, tanda membawa kematian dan sebagainya. Hal ini seterusnya dapat dikaitkan dengan makna implisit peribahasa tersebut iaitu sikap seseorang yang jahat, jika dinasihatkan macam mana sekalipun tidak akan berubah, melainkan individu tersebut mendapat hidayah daripada Allah SWT.

\section{Kesimpulan}

Kajian ini membuktikan bahawa masyarakat Melayu pada zaman dahulu tidak melihat imej perlambangan burung gagak secara "mata zahir", tetapi dengan "mata hati". Hal ini dikatakan demikian kerana walaupun kajian terkini sudah membuktikan bahawa burung gagak sebagai burung yang pintar, dapat menyelesaikan masalah dengan baik dan boleh mengekspresikan perasaan yang kompleks seperti memberi tindak balas jika berlakunya kematian. Tetapi, apa membuktikan "mata hati" masyarakat Melayu begitu tajam adalah kerana dapat menyangkal kajian saintifik burung gagak yang mengekspresikan perasaan yang kompleks seperti memberi tindak balas jika berlakunya kematian, tetapi secara zoologinya burung ini dikenali sebagai pemakan bangkai. Masyarakat Melayu merelasikan kelakuan ini dengan sikap seseorang yang khianat, tikam belakang, ada kepentingan tersendiri dan sentiasa menunggu masa untuk menjatuhkan seseorang. Oleh sebab itulah, masyarakat Melayu masih mengasosiasikan imej perlambangan burung gagak ini dengan perkara yang negatif, walaupun secara zoologi burung gagak ada sifat yang positif. Selain itu, kajian mengenai peribahasa sebelum ini telah dikaji secara semantik skrip dan semantik resonans sehingga dapat menghuraikan makna tersurat dan makna tersirat, teoretikal (tidak pada pengalaman atau amalan) dan kognitif penuturnya. Namun begitu, hajat sebenar yang ingin disampaikan oleh masyarakat Melayu pada zaman dahulu masih belum mencukupi. Sebagai penambahbaikan kajian-kajian lepas, pendekatan merentas disiplin ilmu iaitu semantik inkuisitif berupaya mengaitkan akal budi penutur sehingga jawapan pemilihan imej perlambangan burung gagak dapat dijawab dengan berwibawa. Kajian ini juga mencadangkan supaya pengkaji akan datang meneroka imej perlambangan burung secara khusus seperti "merak", "pipit", "enggang" dan sebagainya, di samping mengaplikasikan SI sebagai tatacara menganalisis data. 


\section{Rujukan}

Abdullah, F. S. (2018, Julai 2). Warna dan psikologi. MyHEALTH-Kementerian Kesihatan Malaysia. http://www.myhealth.gov.my/warna-dan-psikologi/

Abdullah, N. A., \& Daud, M. Z. (2020). Pemaknaan semula sinonim leksikal "nepotisme" berteraskan data korpus: Analisis Pragmatik. LSP International Journal, 7(1), 6179.

Abdullah, W. H. W., Hamdan, M. N., Hehsan, A., Haron, Z., Rosman, A. S., \& Ripin, M. N. (2019). Terapi mandi bunga dalam perubatan Melayu untuk penjagaan kesihatan mental. UMRAN: International Journal of Islamic and Civilizational Studies, 6(2), 123-135.

Anim, H. (2018, Disember 21). Burung bangau di Malaysia. https://animhosnan.blogsp ot.com/2018/12/burung-bangau-di-malaysia.html

Daud, M.Z. (2018a). Domain rezeki dalam peribahasa Melayu berorientasikan Aves melalui perspektif semantik inkuisitif. MALTESAS Multi-Disciplinary Research Journal, 3(1), 19-28.

Daud, M. Z. (2018b). Gallus gallus domesticus dan Paradoxurus hermaphroditus dalam peribahasa Melayu: Analisis semantik inkuisitif. Sains Humanika, 10(2), 41-51.

Daud, M.Z. (2020). Unggas dalam peribahasa Melayu: Satu analisis semantik inkuisitif (Tesis Sarjana, Universiti Malaysia Sarawak).

Daud, M. Z., \& Subet, M. F. (2019a). Ayam (gallus gallus domesticus) dalam peribahasa Melayu: Analisis semantik inkuisitif. Jurnal Kemanusiaan, 17(1), 36-42.

Daud, M. Z., \& Subet, M. F. (2019b). "Sudah tidak tersudu oleh angsa, baru diberikan kepada itik": Perspektif semantik inkuisitif dan akal budi Melayu. Jurnal Melayu Sedunia, 2(1), 37-62.

Daud, M.Z., \& Subet, M.F. (2019c, Oktober 17-18). Elemen perlambangan unggas dalam peribahasa Melayu: Analisis semantik inkuisitif. Kertas persidangan yang dibentang pada Hari Terbuka Fakulti Bahasa dan Komunikasi, Universiti Malaysia Sarawak.

Daud, M. Z., \& Subet, M. F. (2021). Ayam sebagai rujukan makna inkuisitif berhati-hati, sia-sia dan khianat dalam peribahasa Melayu. Kajian Malaysia. http://web.usm.my/km/earlyView_May2021/16_KM-OA-06-19-0071.R4.pdf

Erwany, L. (2016). Tradisi lisan malam berinai pada masyarakat Melayu Tanjung Balai (Disertasi Kedoktoran, Universitas Sumatera Utara).

Hadi, F. L. (2018). Kajian makna dan nilai budaya peribahasa Jepang dan Indonesia yang menggunakan unsur nama binatang. GoKen, 6(2), 1-9.

Hussain, A. (2016). Kamus istimewa peribahasa Melayu (2nd ed.). Dewan Bahasa dan Pustaka.

Ibrahim, S., \& Halid, R. I. R. (2020). Grafik dan muzik: Analisis reka bentuk kulit album. Jurnal Komunikasi, 36(4), 369-394.

Ismail, W. N. I. (2016). Haiwan dalam peribahasa Melayu: Analisis semiotik (Tesis sarjana, Institut Alam dan Tamadun Melayu, Universiti Kebangsaan Malaysia, Bangi, Malaysia). 
Jalaluddin, N. H. (2014). Semantik dan akal budi Melayu. Penerbit Universiti Kebangsaan Malaysia.

Kamus Dewan Edisi Keempat. (2016). Dewan Bahasa dan Pustaka.

Karar, A., Ningsih, S., \& Ihsan, M. (2016). Keanekaragaman jenis burung di hutan primer di Suaka Margasatwa Pulau Pasoso Kecamatan Balaesang Tanjung Kabupaten Donggala. Jurnal Warta Rimba, 4(2), 1-8.

Kempson, R. M. (1986). Ambiguity and the semantics and pragmatics distinction. Dalam C. Travis (Pynt.), Meaning and interpretation (pp. 135-154). Basil Blackwell.

Kusrianto, A. (2009). Pengantar desain komunikasi visual. Penerbit Andi.

Miles, M. B., \& Huberman. (1994). Qualitative data analysis. Sage Publication

Mokhtar, N. A., Sidek, J. H., Mahyuddin, M. K., Zumrah, A. R., Ismail, M., Sabran, R., \& Ghazali, M. R. (2018). Isu dan masalah akidah dan syariah dalam pengubatan spiritual Islam di kalangan masyarakat Islam di Malaysia. Jurnal Ushuluddin Adab dan Dakwah, 1(2), 131-154.

Nopiah, J., Jalaluddin, N. H., \& Kasdan, J. (2017). Refleksi dualisme 'Durian-Timun' dalam peribahasa Melayu: Pendekatan semantik inkuisitif. Jurnal Linguistik, 21(2), 114.

Oemiati, S. (2010). Gaya bahasa perumpamaan simile dalam novel Yukiguni karya Yasunari Kawabata. Jurnal Bahasa dan Sastra, 6(2), 135-145.

Paul, D., Hamzah, N. S., \& Hamid, T. N. A. T. A. (2019). Interpretasi ritual mandi dalam kalangan masyarakat di Malaysia. Asian Journal of Environment, History and Heritage, 3(2), 257-269.

Rahman, M. T. A. (2017). Kamus peribahasa Melayu untuk pelajar. Penerbit Fajar Bakti.

Rahman, N. A. A., Fadzly, N., Dzakwan, N. M., \& Zulkifli, N. H. (2014). The numerical competency of two bird species (Corvus splendens and acridotheres tristis). Tropical Life Sciences Research, 25(1), 95-103.

Ritos, S., \& Daud, M. Z. (2020). Strategi penggantian disfemisme kepada eufemisme dalam komunikasi lisan masyarakat Bidayuh, Bau: Analisis pragmatik. Asian People Journal, 3(1), 64-83.

Said, S. H. (2013). Kamus peribahasa Melayu. Penerbitan Pelangi.

Samaon, S. S., \& Subet, M. F. (2020a). Perwatakan dalam novel KOMSAS "Di Sebalik Dinara": Analisis teori relevan. Asian People Journal, 3(1), 84-100.

Samaon, S. S., \& Subet, M. F. (2020b). Teori relevans dalam pembelajaran KOMSAS. Borneo International Journal, 2(4), 47-54.

Seli, S. (2018). Kearifan tempatan dalam cerita rakyat Dayak Kanayatn: Kajian Hermeneutik (Disertasi Kedoktoran, Universiti Malaya).

Sperber, D., \& Wilson, D. (1986). Relevance: Communication and cognition. Blackwell Publishers.

Studios, M. L. (2020, Mei 17). Burung gagak ingat muka kita. https://www.youtube.com/watch?v=oVEPkLV3EWc

Syauqi, D., Budiwirman, M. P., \& Yofita, S. P. (2018). Burung gagak sebagai ide dalam karya seni grafis. Serupa: The Journal of Art Education, 7(1), 1-20. 
Werema, C. (2015). Under storey bird abundance and diversity before and after a forest fire in Mangala Forest Reserve on the eastern slopes of the Uluguru Mountains, Tanzania. Journal of East African Ornithology, 34(1), 40-46.

Widuri, A. N. (2017). Analisis makna chengyu yang menggunakan unsur binatang berdasarkan konotasi dan fungsinya(Tesis sarjana, Universitas Negeri Semarang).

Zulbadri, B. S., Zuki, N. W. C. M., Tumiran, M. A., Kamarulzaidi, M. A., Musa, M. N., Saat, R. M., ... Yusoff, M. Y. Z. H. M. (2011). Kelakuan burung: Analisis perbandingan dari perspektif rujukan berteraskan Al-quran dan neurosains. QURANICA: International Journal of Quranic Research, 1(1), 139-164. 